\title{
Bioremediasi Logam Berat Pb(II) Dan Cu(II) Pada Air Lindi Menggunakan Chlorella Vulgaris
}

\section{Bioremediation of Heavy Metals Pb (II) And Cu (II) in Leachate Using Chlorella Vulgaris}

\author{
Wiya Elsa Fitri, Chamy Rahmatiqa, Adewirli Putra* \\ Stikes Syedza Saintika, Kota Padang \\ email: adewirliputra@gmail.com
}

\begin{abstract}
Abstrak. Bioremediasi merupakan salah satu upaya penurunan kadar logam berat pada air yang tercemar. Penelitian terkait bioremediasi dalam penurunan kadar logam berat oleh Mikroalga, khususnya Chlorella vulgaris sudah ada, namun, masih sebatas uji penurunan kandungan logam berat skala laboratorium. Belum ada penelitian tentang penurunan kadar Logam Berat pada air lindi. Penelitian ini bertujuan untuk mengetahui konsentrasi logam berat pada Air Lindi TPA Air Dingin, kapasitas penurunan konsentrasi logam berat dan akumulasi logam dalam sel Chlorella vulgaris. Metoda penelitian yang diguanakan adalah metoda ekperimental. Hasil penelitian yang diketahui bahwa Chlorella vulgaris dapat tumbuh baik didalam medium air lindi, terlihat dari pertumbuhan yang signifikan sampai fase stasioner, dan terjadi perubahan warna serta bau. Chlorella vulgaris memiliki kemampuan menurunkan kadar logam $\mathrm{Pb}$ (II) $80,6 \%$ dan $\mathrm{Cu}$ (II) $70,9 \%$ dalam medium. Konsentrasi logam $\mathrm{Pb}$ (II) dan $\mathrm{Cu}$ (II) sel Chlorella vulgaris lebih tinggi bandingkan dengan konsentrasi dalam medium kultur di akhir penelitian dengan Nilai BCF logam $\mathrm{Pb} 5.03$ dan ion $\mathrm{Cu} 3.08$ (BCF>1), yang artinya Chlorella vulgaris merupakan akumulator logam $\mathrm{Pb}$ dan $\mathrm{Cu}$.
\end{abstract}

Kata kunci: Bioremediasi, Logam Berat, Lindi, TPA, Chlorella vulgaris

\begin{abstract}
Bioremediation is an effort to reduce heavy metal levels in polluted water. Research related to bioremediation in reducing heavy metal content by microalgae, especially Chlorella vulgaris already existed, however, it is still limited to testing on a laboratory scale to reduce heavy metal content. There has been no research on the reduction of heavy metal levels in leachate. This study aimed to determine the concentration of heavy metals in the leachate of Air Dingin Landfill, the capacity of heavy metal concentrations reduction and metal accumulation in Chlorella vulgaris cells. The research method used was an experimental method on June until September 2020. The results showed that Chlorella vulgaris could grow well in leachate medium, observed from the significant growth until the stationary phase, and the changes in colour which became greener and the odor which was reduced. Chlorella vulgaris had the ability to reduce $80.6 \%$ of $\mathrm{Pb}$ (II) and $70.9 \% \mathrm{Cu}$ (II) in the medium. The concentration of $\mathrm{Pb}$ (II) and $\mathrm{Cu}$ (II) metal in Chlorella vulgaris cells were higher compared to the concentration in the culture medium at the end of the study with a $B C F$ value of $\mathrm{Pb}$ (II) of 5.03 and $C u(I I) 3.08$ (BCF> 1), which means that Chlorella vulgaris is an accumulator of $\mathrm{Pb}(\mathrm{II})$ and $\mathrm{Cu}(\mathrm{II})$ metal.
\end{abstract}

Keywords : Bioremediation, Heavy metal, Leachate, Landfill, Chlorella vulgaris 


\section{PENDAHULUAN}

Tingginya kepadatan penduduk membuat konsumsi masyarakat pun semakin tinggi, Hal ini menjadi latar belakang polemik peningkatan jumlah sampah yang dihasilkan masyarakat setiap hari. Jumlah penduduk Kota Padang saat ini sekitar 900 ribu jiwa dan menghasilkan 666 ton sampah setiap harinya (Audina, 2018). Dari angka tersebut, baru 100 ton yang bisa dikelola menjadi kompos atau didaur ulang. Sekitar, 500 ton sisanya harus ditimbun di TPA Air Dingin. Dari 100 ton sampah yang diolah, 65 persen merupakan sampah organik yang bisa dijadikan kompos dan 35 persen merupakan sampah plastik dan kertas yang bisa didaur ulang (DLH Kota Padang, 2019). Timbunan sampah berdampak langsung maupun tidak langsung pada manusia, seperti berbagai penyakit menular maupun penyakit kulit, gangguan pernafasan serta dapat mengganggu kesehatan manusia dan mengganggu estetika lingkungan (Purnamawat, Soeprobowati, Retnaningsih, \& Izzati, 2015).

TPA Air Dingin ini mempunyai luas lahan sebesar 33 Ha dan mulai dioperasikan semenjak tahun 1989 dengan system pengoperasian open dumping dengan lahan yang telah dioperasikan sekitar 60\% dari luas lahan yang ada (DLH Kota Padang, 2019),(Nurhayati, Hamzah, \& Pambayun, 2014). Selain timbunan sampah, Air Lindi merupakan salah satu masalah dari system pegelolaan sampah secara Open Dumping. Berdasarkan hasil survey awal, yang dilakukan, terdapat 4 bak Treatment Air Lindi di TPA Air Dingin. Namun, saat ini bak tersebut sudah dalam kondisi yang tidak memadai. Kondisi tersebut akan berdampak pada pencemaran lingkungan disekitar TPA dan dapat membahayakan masyarakat sekitar (Audina, 2018).

Logam berat merupakan senyawa kimi berbahaya yang terakumulasi pada Air Lindi. Beberapa jenis logam berat seperti Merkuri (Hg), Kadmium (Cd), Timbal (Pb), Arsen (As) dan beberapa lainnya merupakan logam yang beracun terhadap makhluk hidup. Bahan kimia anorganik tersebut dapat menyebabkan keracunan akut maupun kronis, bergantung pada jenis logamnya, jumlahnya, spesies hewan, kondisi hewan, dan umurnya berdampak serius terutama pada manusia, seperti menyebabkan kerusakan sel, organ bahkan sampai menyebabkan kematian(Ali, 2011),(Palar, 2008).

Untuk mengatasi cemaran logam dari resapan air lindi, perlu dilakukan upaya pengolahan air lindi, dengan syarat tidak menambah kerusakan lingkungan. Salah satu upaya mengendalian yang dapat dilakukan sesuai standar tersebut adalah remediasi senyawa logam berat menggunakan tumbuhan hijau (Fitoremediasi)(Ibrahim, 2017). Biomasa microalga merupakan biosorben yang paling banyak digunakan saat ini (Putra \& Fitri, 2016). Salah satu mickroalga yang berpotensi meremediasi logam berat adalah Chlorella vulgaris $(\mathrm{Cv})$. Beberapa penelitian menunjukkan potensi luar biasa $\mathrm{Cv}$ sebagai fitoremediator seperti kemampuannya dalam mengikat $\mathrm{CO}_{2}$ (Ibrahim, 2017),(Keffer \& Kleinheinz, 2002), mampu menyerap nitrogen dan fosfat (Sekabira, Origa, Basamba, Mutumba, \& Kakudidi, 2011),(Isnansetyo \& Kurniastuty, 1995), penurunan cemaran limbah industri (Yun, Kim, Kwon, Kang, \& Om, 2011), Logam berat dan Air Lindi.(Ibrahim, 2017),(Sekabira et al., 2011),(Shim et al., 2008).

Penelitian terkait dengan penurunan kadar logam berat oleh Cv masih hanya sebatas uji penurunan kandungan logam berat skala laboratorium (Ibrahim, 2017). Belum ada penelitian tentang penurunan kadar Logam Berat oleh $\mathrm{Cv}$ pada air lindi. Penelitian ini bertujuan untuk mengetahui Konsentrasi Logam Air Lindi TPA Air Dingin, Mengetahui Presentase penurunan konsentrasi logam dalam medium dan 
Mengetahui Akumulasi logam dalam sel Cv. Penelitian ini sangat penting sebagai upaya untuk pengendalian dampak pencemaran lingkungan akibat Air Lindi TPA Air Dingin yang mengancam masyarakat sekitarnya. Hasil dari penelitian ini diharapkan dapat menjadi referensi dan masukan dalam pengolahan Air Lindi di TPA..

\section{METODE PENELITIAN}

\subsection{Waktu dan Tempat Penelitian}

Penelitian ini telah dilaksanakan dari bulan Juni sampai September 2020 di Laboratorium Dasar Stikes Syedza Saintika. Pengambilan sampel air lindi TPA Air Dingin Kota Padang. Untuk analisis kadar logam dilakukan di Laboratorium Instrumen LLDIKTI Wilayah X

\subsection{Alat dan Bahan}

Peralatan yang digunakan dalam penelitian ini adalah AAS, Autoclave, mikroskop binokuler, lampu neon, toples kaca ukuran 3 liter, aerator, handy counter, thermometer, $\mathrm{pH}$ meter, kaca preparat, Neubauer hemositometer, pipet ukur, gelas ukur, erlemeyer dan pipet tetes.

Bahan penelitian adalah biakan $\mathrm{Cv}$ yang didapatkan dari Balai Besar Pengembangan Budidaya Air Payau (BBPBAP) Jepara, larutan Walne, larutan logam $\mathrm{Pb}\left(\mathrm{NO}_{3}\right)_{2}, \mathrm{CuSO}_{4}, \mathrm{HNO}_{3}$, Aquadest, Air Laut, Air Lindi, Pupuk Walne.

\subsection{Metode Penelitian}

Metode penelitian yang digunakan adalah metode eksperimental dengan Rancangan percobaan rancangan acak lengkap (RAL) dengan memperbandingkan pertumbuhan $\mathrm{Cv}$ pada media Kontrol dan air lindi dengan tiga kali pengulangan,

\subsection{Prosedur Penelitian}

\subsubsection{Sterilisasi Alat dan Bahan}

Sterilisasi alat dan bahan bertujuan menghilangkan kontaminasi dari mikroorganisme yang tidak diinginkan. Air laut yang distrilisasi digunakan untuk media kultur $\mathrm{Cv}$ menggunakan autoclave. Air yang telah disterilisasi kemudian disimpan dalam botol tertutup.

Sterilisasi alat-alat dari kaca dilakukan dengan menggunakan autoclave. Sebelum digunakan, peralatan dicuci dengan tipol kemudian dibilas dengan air tawar, dikeringkan, kemudian dibungkus dengan aluminium foil. Setelah itu dimasukkan dan diatur rapi dalam autoclave, ditutup rapat dan dioperasikan dengan suhu $121{ }^{\circ} \mathrm{C}$. Setelah proses selesai, botol kultur dikeluarkan dari autoclave dan disimpan pada wadah yang bersih. Selang dan batu aerasi disterilisasi dengan cara dicuci terlebih dahulu dengan tipol yang kemudian di bilas dengan aquadest.

\subsubsection{Pembuatan Medium Tumbuh Chlorella Vulgaris}

Air Lindi yang diperoleh dari TPA Air Dingin langsung dibawa ke Laboratorium. Bibit $\mathrm{Cv}$ tersebut diperoleh dari Laboratorium Balai Besar Pengembangan Budidaya Air Payau (BBPBAP)(Dewi \& Nuravivah, 2018). Kultur Cv yang digunakan dilakukan uji viabilitas terlebih dahulu, selanjutnya pada penelitian ini akan disiapkan 4 bak kultur, yaitu: 
1. 3 bak kultur yang berisi $1 \mathrm{~L}$ Air Lindi dengan penambahan $500 \mathrm{ml}$ Biakan murni $\mathrm{Cv}$ (kepadatan yang sama untuk seluruh bak) dan $10 \mathrm{ml}$ pupuk walne

2. 1 bak kultur yang berisi $1 \mathrm{~L}$ Aquadest Steril $+500 \mathrm{ml}$ Biakan murni $\mathrm{Cv}+10 \mathrm{ml}$ pupuk walne (tanpa penambahan Air Lindi) sebagai kontrol

Guna memperoleh kepadatan awal $\mathrm{Cv}$ tersebut digunakan rumus :

$$
\mathrm{V}_{1} \cdot \mathrm{N}_{1}=\mathrm{V}_{2} \cdot \mathrm{N}_{2}
$$

$\mathrm{V}_{1}=$ volume inokulum yang diinginkan,

$\mathrm{N}_{1}=$ kepadatan stok $(\mathrm{sel} / \mathrm{ml})$

$\mathrm{V}_{2}=$ volume medium kultur

$\mathrm{N}_{2}=$ kepadatan sel yang diinginkan

Sumber cahaya berasal dari cahaya lampu neon 36 watt.

\subsubsection{Kepadatan Sel}

Kepadatan sel Cv dihitung menggunakan hemositometer Neubauer Improved dan mikroskop Olympus binokuler pada perbesaran lensa objektif 40x. Sampel yang terdapat pada botol percobaan diambil $2 \mathrm{ml}$. Pengukuran kepadatan dilakukan setiap hari. Pengamatan sel pada hemositometer untuk setiap bak kultur dilakukan empat kali ulangan pada setiap bidang pandang hemositometer. Kepadatan sel dihitung menggunakan rumus sebagai berikut :

Keterangan :

$$
\mathrm{N}=\mathrm{n} \times 10^{4}
$$

$\mathrm{N}=$ kelimpahan fitoplankton (sel/ml);

$\mathrm{n}=$ Jumlah organisme

Pengukuran Logam Berat dengan menggunakan AAS di Laboratorium LLDIKTI Wilayah $\mathrm{X}$ dan dibutuhkan senyawa logam berat dalam pembuatan kurva standar. Pengukuran Logam berat dilakukan sebanyak 4 kali pengamatan, yaitu:

1. Hari 0 , pengukuran logam berat $\mathrm{Pb}(\mathrm{II})$ dan $\mathrm{Cu}(\mathrm{II})$ sebanyak 3 kali pengulangan sebagai data awal

2. Hari ke 7, 14 dan 21, masing-masingnya dilakukan pengukuran logam berat

\subsubsection{Parameter Penelitian}

1. Kualitas Media Tumbuh Cv

2. Pertumbuhan $\mathrm{Cv}$ yang dipaparkan dengan Air Lindi

3. Kapasitas Penyerapan Logam $\mathrm{Pb}$ (II) dan $\mathrm{Cu}$ (II) dalam Air Lindi

4. NIlai BCF Cv pada air Lindi

\section{HASIL PENELITIAN DAN PEMBAHASAN}

\subsection{Parameter Kualitas Media Tumbuh Chlorella vulgaris}

Pertumbuhan mikroalga secara langsung maupun tidak langsung sangat dipengaruhi oleh kualitas lingkungan, meliputi parameter fisika dan kimia. Pengukuran parameter fisika kimia lingkungan pada penelitian ini dilakukan sebanyak 3 kali ulangan 
Dalton : Jurnal Pendidikan Kimia dan Ilmu Kimia, Volume 4 Nomor 1, Mei 2021

pada bak control dan 3 bak lindi yang dirata-ratakan dengan nilai yang dapat dilihat pada table 1.

Tabel 1. Rata-Rata Nilai Parameter Kualitas Air pada Media Chlorella vulgaris

\begin{tabular}{cccccc}
\hline Parameter Media Kultur & Suhu & pH & Warna & Bau \\
\hline H0 & Kontrol & 27.4 & 7 & Hijau muda & Tidak Berbau \\
Kindi & 28.2 & 7.8 & $\begin{array}{c}\text { Kuning } \\
\text { Kecoklatan }\end{array}$ & Menyengat \\
\hline H7 & Kontrol & 28.2 & 7 & Hijau Terang & Tidak Berbau \\
& Lindi & 28.6 & 8 & Kuning Kehijauan & Menyengat \\
H14 & Kontrol & 28.2 & 7 & Hijau Pekat & Tidak Berbau \\
& Lindi & 28.4 & 7.6 & Hijau Terang & Kurang Menyengat \\
\hline H21 & Kontrol & 27 & 7.2 & Hijau Tua & Tidak Berbau \\
& Lindi & 28 & 7.6 & Hijau Tua & Kurang Menyengat \\
\hline
\end{tabular}

Dari data hasil penelitian, diketahui rata-rata suhu air berkisar antara 27.4 -28.6 ${ }^{\circ} \mathrm{C}$ baik pada bak kontrol maupun air lindi. Suhu air selama penelitian cendrung mengalami peningkatan pada hari ke 7 dan 14, namun mengalami sedikit penurunan pada hari ke 21. Suhu selama penelitian mempengaruhi aktivitas metabolisme organisme, selain itu suhu sangat berpengaruh terhadap kehidupan dan pertumbuhan biota air. Suhu pada hasil pengamatan sudah memenuhi kriteria, dimana $\mathrm{Cv}$ dapat tumbuh dengan baik pada suhu 25-30 ${ }^{\circ} \mathrm{C}$ (Hartanto, Hariyati, \& Soeprobowati, 2013). Perubahan suhu berpengaruh terhadap proses kimia, biologi dan fisika, peningkatan suhu dapat menurunkan suatu kelarutan bahan dan dapat menyebabkan peningkatan kecepatan metabolisme dan respirasi mikroalga di perairan (Kurniawan \& Aunurohim, 2014), namun peningkatan suhu yang ekstrim dapat menyebabkan kematian (Singh, 2015).

pH media tumbuh berkisar antara 7 sampai 8. Pada Bak control, pada H0 (awal) sampai hari ke 14 nilai pH rata-rata 7, merupakan nilai normal (Putra \& Fitri, 2019). Nilai $\mathrm{pH}$ ini sesuai untuk media hidup $C v, \mathrm{pH}$ optimum untuk pertumbuhan $C v$ adalah 67 (Halima, Effendi, \& Ambarsari, 2019)'(Regaldo, Gervasio, Troiani, \& Gagneten, 2013). Pada Bak Lindi terjadi peningkatan pH dari H0 sampai hari ke 14 dan mengalami penurunan pada hari ke 14 dan 21. Peningkatan $\mathrm{pH}$ bergubungan dengan peningkatan kepadatan mikroalga yang signifikan sampai haperubahan nilai ke 14. Hal ini disebabkan adanya aktivitas fotosintesis mikroalga pada saat fotosintesis, $\mathrm{CO}_{2}$ bebas merupakan jenis karbon anorganik utama yang digunakan mikroalga berupa ion karbonat $\left(\mathrm{CO}_{3}{ }^{2-}\right)$ dan bikarbonat $\left(\mathrm{HCO}_{3}^{-}\right)$. Penyerapan $\mathrm{CO}_{2}$ bebas dan bikarbonat oleh mikroalga menyebabkan penurunan konsentrasi $\mathrm{CO}_{2}$ terlarut dan mengakibatkan peningkatan nilai $\mathrm{pH}$. Selain itu, penguraian penguraian protein dan persenyawaan nitrogen turut menjadi penyebab terjadinya peningkatan $\mathrm{pH}$ pada media limbah. 
Amonium $\left(\mathrm{NH}_{4}{ }^{+}\right)$, nitrat $\left(\mathrm{NO}_{3}{ }^{-}\right)$dan nitrit $\left(\mathrm{NO}_{2}^{-}\right)$merupakan bentuk senyawa nitrogen organik yang telah mengalami penguraian. Pada umumnya, senyawa nitrogen yang digunakan dalam metabolisme sel mikroalga berupa amonium. Amonium dihasilkan melalui proses disosiasi amonium hidroksida. Amonium hidroksida merupakan amonia yang terlarut dalam air (Znad, Ketife, Judd, Almomani, \& Vuthaluru, 2018).

Warna air kontrol pada hari pertama berwarna hijau muda dan semakin lama semakin pekat, sedangkan bak yang berisi air lindi, semakin lama warna kuning kecoklatan berubah menjadi kehijauan dan semakin pekat. Untuk bak yang berisi air lindi pada awalnya berbau menyengat, namun, semakin lama, bau semakin berkurang. Perubahan warna pada air lindi menjadi lebih terang dan kehijauan serata semakin berkurangnya bau menyengat setiap harinya berh semakinbungan langsung dengan meningkatnya kepadatan alga yang mampu menguraikan senyawa organic terlarut dalam limbah. Menurut Nurhayati, (2014) bahwa berfluktuasinya kadar BOD disebabkan oleh semakin banyaknya biomasa mikroalga yang terbentuk akibat pertambahan sel, sehingga zat organik yang harus didegradasi pun bertambah seiring meningkatnya pertumbuhan.

Dari hasil peneltian terlihat bahwa parameter kulitas Air yang umumnya cukup optimum. Komunitas mikroalga pada suatu perairan dipengaruhi oleh kondisi lingkungan antara lain temperature/suhu, intensitas cahaya, derajat keasaman $(\mathrm{pH})$, aerasi sumber $\mathrm{O}_{2}$ (Halima, Nursyirwani, Effendi, \& Ambarsar, 2020)

\subsection{Pertumbuhan Cv yang di Paparkan dengan Air Lindi}

Pengkuran Pertumbuhan Cv dilakukan setiap hari selama 21 hari terhadap setiap bak, baik Bak Kontrol maupun bak lindi yang dirata-ratakan. Pengukuran dilakukan dengan cara menghitung jumlah sel $\mathrm{Cv}$ menggunakan Hemocytometer dan hasil disajikan pada gambar 1.

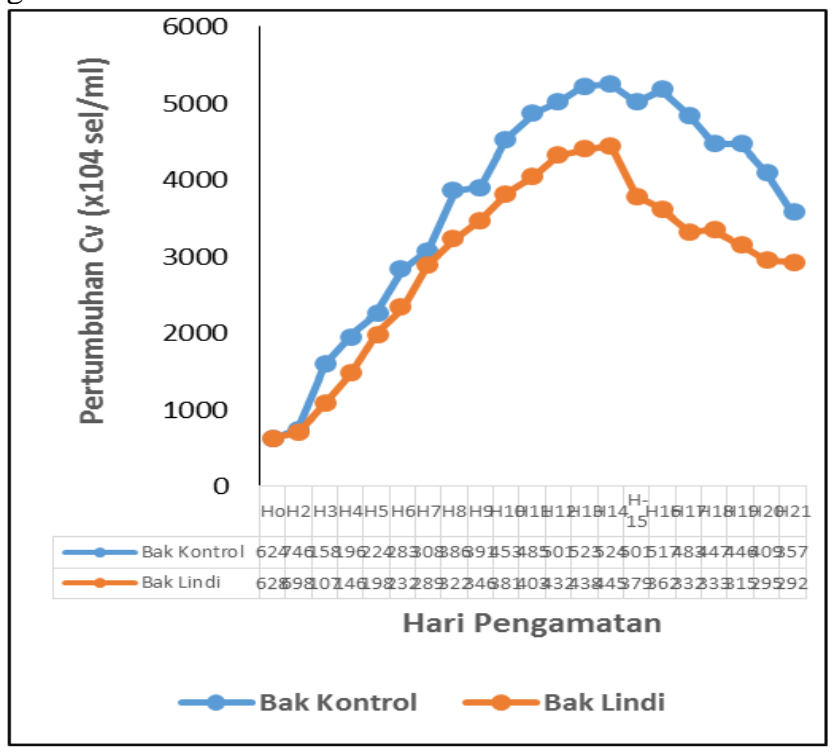

Gambar 1. Laju pertumbuhan Cv pada media air laut dan air lindi 
Hasil dari pengujian selama penelitian dapat dilihat pada Gambar 1. Pola pertumbuhan yang dimiliki mikroalga $C v$ dimulai dari fase lag (adaptasi) pada hari petama dipindahkan ke dalam media tumbuh (H ke 0) sampai hari ke-3. Pada Fase lag, $\mathrm{Cv}$ belum terlalu aktif melakukan pembelahan diri, namun, $\mathrm{Cv}$ masih tetap melakukan fotosintetis dan bermetabolisme dan memepersiapkan diri untuk melakukan pembelahan atau reproduksi sel, kondisi ini dibuktikan dengan warna kultur menjadi lebih pekat dari warna kultur pada hari sebelumnya. Selama masa adaptasi sel-sel memulihkan enzim dan konsentrasi substrat ke tingkat yang diperlukan untuk pertumbuhan serta masuknya unsur hara ke dalam sel fitoplankton terjadi melalui proses difusi sebagai akibat perbedaan konsentrasi antara media kultur dengan cairan tubuh (Chilmawati \& Suminto, 2008). Pada penelitian ini penambahan jumlah sel mulai terjadi pada hari ke 2, yang berarti fase lag cukup singkat. Lama nya adaptasi berbeda-beda untuk setiap organisme dan juga dipengaruhi oleh beberapa faktor seperti nutrisi, budaya, dan radiasi (Pereira \& Neto, 2015).

Pertumbuhan sel $\mathrm{Cv}$ pada fase eksponensial terjadi pada hari ke 4-13,dimana pembelahan sel sangat optimal ditandai dengan peningkatan kepadatan da biomassa yang tajam (Dewi, 2015). Salah satu faktor penentu pertumbuhan $\mathrm{Cv}$ adalah media tumbuh yang digunakan. Pada penelitian ini digunakan pupuk walne pada semua perlakuan. Media walne merupakan media tumbuh yang baik bagi Cv karena media ini memiliki kandungan nutrisi yang dibutuhkan oleh $\mathrm{Cv}$, diantaranya adalah nitrogen, fosfor, vitamin B12 karena vitamin B12 berguna bagi pertumbuhan selnya dan alga ini tidak dapat menghasilkannya sendiri.

Setelah hari ke 13-14, Biomassa Cv cendrung konstan pada bak air lindi maupun kontrol. Dalam hal ini $\mathrm{Cv}$ mengalami fase stasioner, yaitu fase puncak yang konstan, dan setelah hari ke 15 mulai mengalami penurunan pada kedua bak perlakuan (death phase). Penurunan populasi ini disebabkan karena jumlah nutrient yang terkandung dalam media juga terbatas, karena tidak dilakukannya penambahan nutrient sehingga $\mathrm{Cv}$ tidak mampu lagi mempertahankan kepadatannya lagi (Musa, Raya, \& Dali, 2013). Fase kematian terjadi karena ketersediaan nutrisi sudah sangat berkurang sehingga tidak mencukupi untuk pertumbuhan dan pembelahan sel (Barsanti \& Gualtieri, 2006)' (Borowitzka, 1997).

Pada kurva pertumbuhan (gambar 1) terlihat bahwa pertumbuhan $\mathrm{Cv}$ pada bak lindi lebih rendah dibandingkan bak kontrol. Air Lindi mengandung senyawa komplek, baik organic maupun an organic, seperti logam salah satunya. Kandungan logam tersebut dapat menjadi penghambat pertumbuhan $\mathrm{Cv}$. Logam berat dapat mengahambat pertumbuhan pada beberapa algae hijau karena logam berat dapat menurunkan kandungan protein, karbohidrat, pigmen fotosintesis, Proses metabolisme nitrat serta respirasi. Pembelahan $\mathrm{Cv}$ yang terhambat ini dapat disebabkan oleh pergantian pada struktur membran tilakoid kloroplas akibat adanya Logam berat, sehingga terjadi penghambatan fotosintesis (Halima et al., 2019). Meskipun demikian, $\mathrm{Cv}$ tetap dapat tumbuh dengan baik pada medium lindi. Hal ini disebabkan karena $\mathrm{Cv}$ memiliki kemampuan adaptasi pada lingkungan tercemar karena memiliki polyamine, yang berperan sebagai molekul yang mampu melindungi tanaman terhadap resiko tekanan dari lingkungan (Purnamawati, Soeprobowati, \& Izzati, 2013a). Faktor lingkungan mempengaruhi aktivitas mikroorganisme untuk mempertahankan diri dari kontaminasi 
logam berat. Karakteristik mikroorganisme berbeda-beda dan secara langsung dapat mempengaruhi aktivitasnya di suatu lingkungan tertentu (Mallick \& Rai, 1993).

\subsection{Kapasitas Penyerapan Logam Pb(II) dan Cu (II) Dalam Air Lindi}

Dari gambar 2 terlihat kapasitas penyerapan logam $\mathrm{Pb}$ (II) dan $\mathrm{Cu}$ (II) dalam air

lindi.

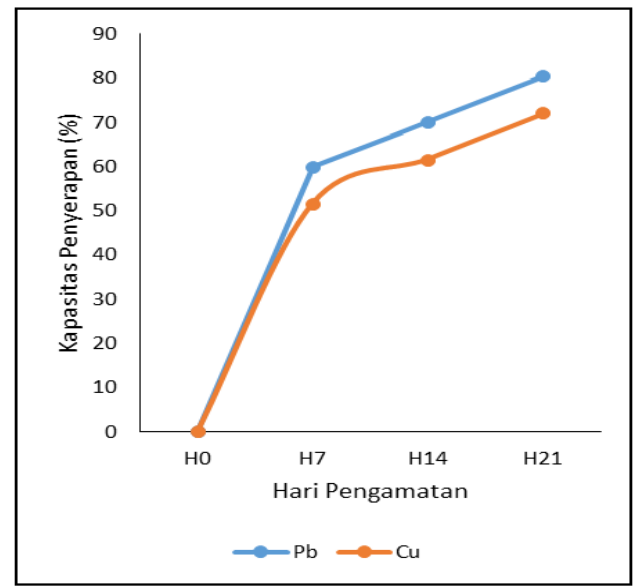

Gambar 2. Kapasitas penyerapan logam $\mathrm{Pb}$ (II) dan $\mathrm{Cu}$ (II) dalam air lindi

Berdasarkan grafik diatas, dapat dilihat bahwa rata-rata persentase penurunan logam berat pada logam $\mathrm{Pb}$ (II) sebesar $80.6 \%$ dan $\mathrm{Cu}(\mathrm{II}) 71.9 \%$ selama 21 hari percobaan. Dari hasil tersebut diketahui bahwa Cv memiliki kemampuan yang baik dalam menurunkan kadar logam berat pada air lindi. Secara umum kapasitas penyerapan logam berat meningkat seiring dengan bertambahnya waktu. Semakin tinggi konsentrasi logam yang diberikan maka semakin besar penyerapan logam tesebut, sebaliknya jika konsentrasinya rendah maka kemampuan $\mathrm{Cv}$ dalam menyerap logam tersebut juga rendah. Sebagaimana pendapat ini juga didukung oleh penelitian yang dilakukan Widiyani, (2014) menyatakan bahwa peningkatan kemampuan biasorbsi logam berbanding lurus dengan peningkatan konsentrasi. Namun penyerapan tidak terlalu signifikan di hari ke 14 dan ke 21 hal ini dikarenakan keberadaan logam berat $\mathrm{Pb}(\mathrm{II})$ secara umum mampu menghambat pertumbuhan populasi $\mathrm{Cv}$, hal ini diduga karena $\mathrm{Cv}$ mengasorpsi kandungan logam berat $\mathrm{Pb}$ (II) dalam media kultivasi. Konsentrasi logam $\mathrm{Pb}$ (II) yang bersifat toksit yang teradsorpsi sel tinggi sehingga sel tidak mampu untuk menetralkannya, dan mempengaruhi tingkat kerusakan sel Cv sehingga mempengaruhi proses pembelahan sel.(Yonita Ike Putri Dyniari, Farikhah, \& Rahim, 2019)

Kemudian kapasitas penyerapan $\mathrm{Cu}$ tidak sebesar $\mathrm{Pb}(\mathrm{II})$ hal ini diperkirakan bahwa ion logam $\mathrm{Cu}(\mathrm{II})$ sebagian berfungsi untuk proses pembelahan sel $\mathrm{Cv}$ karena pada tanaman, $\mathrm{Cu}(\mathrm{II})$ berperan sebagai aktivator beberapa enzim dalam proses pertumbuhan dan juga merupakan salah satu unsur yang berfungsi untuk pembentukan klorofil selama fotosintesis. $\mathrm{Cu}$ (II) memiliki peranan dalam transfer elektron dari fotosistem II ke fotosistem I, dimana $\mathrm{Cu}$ (II) mereduksi menjadi $\mathrm{Cu}(\mathrm{I})$ dalam 
plastosianin, $\mathrm{Cu}(\mathrm{II})$ merupakan kofaktor dari katalase, peroksidase dan superoksidase (Musa et al., 2013)

\subsection{Pengukuran Nilai BCF}

Faktor biokonsentrasi (BCF) merupakan koefisien untuk mengelompokkan efisiensi akumulasi elemen toksik dalam biota dan mediumnya. Nilai ini diperoleh dari hasil pengukuran Konentrasi logam didalam biota dibagi dengan konsentrasi logam dalam medium setelah 21 hari pengamatan. Nilai BCF Cv dalam mengakumulasi logam dapat dilihat pada grafik berikut Gambar 3.

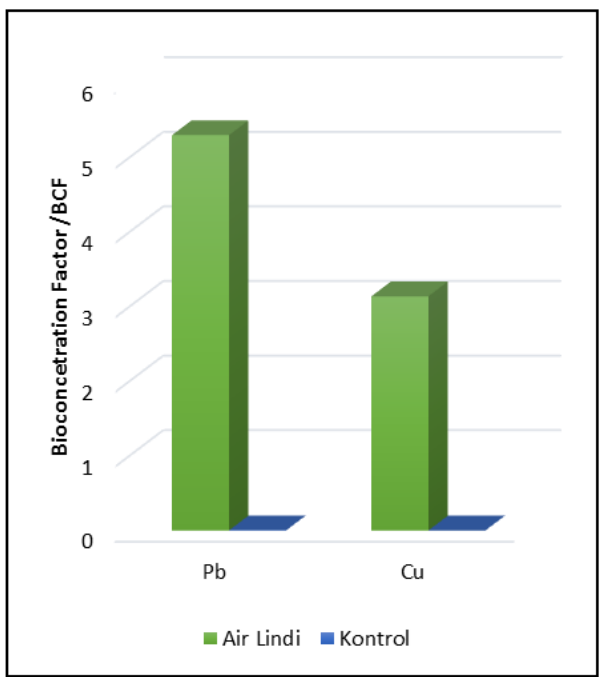

Gambar 3. Kurva Nilai BCF Chlorella vulgaris dalam mengakumulasi logam berat

BCF merupakan koefisien untuk mengelompokkan efisiensi akumulasi elemen toksik dalam biota dan mediumnya. $C$ vmerupakan akumulator logam $\mathrm{Pb}$ (II) dan $\mathrm{Cu}(\mathrm{II})$ karena nilai BCF > 1 (gambar 3). Mikroalga memiliki kemampuan untuk menyerap logam berat dari lingkungan dan mengakumulasikan logam tersebut didalam selnya pada saat metabolisme dan pertumbuhan berlangsung, baik secara proses nonmetabolik (adsorption) ataupun metabolik (absorption) (Bulgariu \& Gavrilescu, 2015).

Nilai $\mathrm{BCF}$ logam $\mathrm{Pb}$ (II) 5.03 dan ion $\mathrm{Cu}$ (II) 3.08 dalam sel $\mathrm{Cv}$ lebih tinggi bandingkan dengan konsentrasi dalam medium kultur di akhir penelitian. Apabila paparan bahan toksik berlangsung terus menerus sel akan mengalami bioakumulasi. Fitoplankton dapat digunakan sebagai agen kelat bagi logam berat yang terlarut dalam badan air. Menurut Haryoto \& Wibowo, (2004), beberapa senyawa organik dalam tubuh fitoplankton, termasuk klorofil, mampu mengikat logam berat membentuk senyawa kompleks melalui gugus-gugus yang reaktif terhadap logam berat seperti sulfidril dan amina. Ikatan kompleks tersebut menyebabkan logam berat menjadi lebih stabil dan terakumulasi dalam sel fitoplankton (Purnamawati et al., 2013a)'(Florensia et al, 2013). 


\section{SIMPULAN}

Pertumbuhan $\mathrm{Cv}$ pada air lindi sangat ditentukan dan dipengaruhi oleh kondisi lingkungan bila dibandingkan dengan pertumbuhannya pada media kontrol. Secara umum $\mathrm{Cv}$ dapat digunakan dalam remediasi kadar logam berat dalam air lindi di TPA Air Dingin.

\section{UCAPAN TERIMA KASIH}

Terimakasih penelti sampaikan kepada DRPM RISTEK-BRIN yang telah mendanai Penelitian Dosen Pemula tahun anggaran 2020-2021, dan juga kami ucapkan terimaksih pada civitas akademika Stikes Syedza Saintika telah mensuport penelitian ini hingga terlaksana dengan baik.

\section{DAFTAR RUJUKAN}

Ali, M. (2011). Rembesan Air Lindi (Leachate) Dampak Pada Tanaman Pangan dan Kesehatan. Surabaya: UPN Press.

Audina, M. (2018). Prediksi Dan Analisis Tempat Pembuangan Akhir (Tpa) Sampah Di Kota Padang. Jurnal Buana, 2(2), 423.

Barsanti, L., \& Gualtieri, P. (2006). Algae: Anatomy, Biochemistry, and Biotechnology (1st ed.). New York: CRC Press.

Borowitzka, M. A. (1997). Microalgae for aquaculture: Opportunities and constraints. Journal of Applied Phycology, 9, 393.

Bulgariu, L., \& Gavrilescu, M. (2015). Bioremediation of Heavy Metals by Microalgae. Handbook of Marine Microalgae. Elsevier Inc.

Chilmawati, D., \& Suminto. (2008). Penggunaan Media Kultur Yang Berbeda Terhadap Pertumbuhan Chlorella Sp. Jurnal Saintek Perikanan, 4(1), 42-49.

Dewi, E. R. S. (2015). Respon Penurunan Konsentrasi Logam Berat Kromium (Cr) dan Pertumbuhan Mikroalga Chlorella vulgaris pada Media Kultur. In Seminar Nasional Konservasi dan Pemanfaatan Sumber Daya Alam 2015 (pp. 117-121). Semarang, Indonesia.

Dewi, E. R. S., \& Nuravivah, R. (2018). Potential of Microalgae Chlorella vulgaris As Bioremediation Agents of Heavy Metal Pb (Lead) On Culture Media. In E3S Web of Conferences , 31, 3-6.

DLH Kota Padang. (2019). Permasalahan Sampah di Kota Padang. Retrieved from http://dlh.padang.go.id/mengurai-permasalahan-sampah-di-kota-padang

Halima, A., Effendi, I., \& Ambarsari, H. (2019). Potential Microalga Chlorella Vulgaris For Bioremediation Of Heavy Metal Pb(II). Asian Journal of Aquatic Sciences, 2(12), 224-234.

Halima, A., Nursyirwani, N., Effendi, I., \& Ambarsar, H. (2020). Potential Microalga Chlorella Vulgaris For Bioremediation Of Heavy Metal Pb(II). Asian Journal of Aquatic Sciences, 2(3), 224-234.

Hartanto, H. S. B., Hariyati, R., \& Soeprobowati, T. R. (2013). Pertumbuhan Populasi Chlorella Vulgaris Beijerinck Dengan Perlakuan Penambahan Logam Berat Tembaga ( Cu ) Pada Skala Laboratorium. Jurnal Akademika Biologi, 2(1), 1927.

Haryoto, H., \& Wibowo, A. (2004). Kinetika Bioakumulasi Logam Berat Kadmium 
Oleh Fitoplankton Chlorella sp. Lingkungan Perairan Laut. Jurnal Penelitian Sains \& Teknologi, 5(2), 89-103.

Ibrahim, F. H. (2017). Phytoremediation in Removing Selected Heavy Metals from Aqueous Solutions. Mesopot. J. Mar. Sci, 32(2), 78-87.

Isnansetyo, A., \& Kurniastuty. (1995). Teknik kultur phytoplankton zooplankton: pakan alami untuk pembenihan organisme laut (1st ed.). Yogyakarta: Kanisius Press.

Keffer, J. E., \& Kleinheinz, G. T. (2002). Use of Chlorella vulgaris for CO2 mitigation in a photobioreactor. Journal of Industrial Microbiology and Biotechnology, 29(5), 275-280.

Kurniawan, J. I., \& Aunurohim. (2014). Biosorpsi Logam Zn2+ dan Pb2+ oleh Mikroalga Chlorella SP. Jurnal Sains Dan Seni ITS, 3(1), 2337-3520.

Mallick, N., \& Rai, L. C. (1993). Influence of culture density, pH, organic acids and divalent cations on the removal of nutrients and metals by immobilized Anabaena doliolum and Chlorella vulgaris. World Journal of Microbiology and Biotechnology, 9(2), 196-201.

Musa, B., Raya, I., \& Dali, S. (2013). Pengaruh Penambahan Ion Cu(II) Terhadap Laju Pertumbuhan Fitoplankton. Makasar, Indonesia.

Nurhayati, C., Hamzah, B., \& Pambayun, R. (2014). Pengaruh pH , Konsentrasi Isolat Chlorella Vulgaris Dan Waktu Pengamatan Terhadap Tingkat Cemaran Limbah Cair Crumb Rubber. Jurnal Dinamika Penelitian Industri, 25(2), 97-106.

Palar, H. (2008). Pencemaran dan Toksikologi Logam Berat. Jakarta: PT. Rineka Cipta.

Pereira, L., \& Neto, J. M. (2015). Marine macroalgae: General Aspect. In Marine Algae: Biodiversity, Taxonomy, Environmental Assessment, and Biotechnology (pp. 159). Portugal: CRC Press, Taylor \& Francis Group.

Puput Widiyani, E. R. S. D. (2014). Penurunan Konsentrasi Logam Berat Kadmium (Cd) Dan Pertumbuhan Mikroalga Chlorella Vulgaris Pada Media Kultur. Bioma, 3(2), 17-26. https://doi.org/10.26877/bioma.v3i2

Purnamawat, F. S., Soeprobowati, Retnaningsih, T., \& Izzati, M. (2015). Potensi Chlorella vulgaris Beijerinck Dalam Remediasi Logam Berat Cd Dan Pb Skala Laboratorium. Bioma : Berkala Ilmiah Biologi, 16(2), 102-113.

Purnamawati, F. S., Soeprobowati, T. R., \& Izzati, M. (2013a). Pemanfaatan Mikroalga Sebagai Biosorben Pada Proses Biosorpsi Logam Berat. In Seminar Nasional Biologi 2013 (Vol. 2, pp. 104-116). Semarang, Indonesia.

Purnamawati, F. S., Soeprobowati, T. R., \& Izzati, M. (2013b). Pertumbuhan Chlorella Vulgaris Beijerinck Dalam Medium Yang Mengandung Logam Berat Cd Dan Pb Skala Laboratorium. In Seminar Nasional Biologi 2013 (pp. 104-117). Semarang, Indonesia.

Putra, A., \& Fitri, W. E. (2016). Karakterisasi Pertukaran Ion Timbal (II) dengan Kalsium pada Proses Biosorpsi Alga Hijau Cladophora fracta. Jurnal Ipteks Terapan, 10(2), 103-111.

Putra, A., \& Fitri, W. E. (2019). Efektivitas Multi Soil Layering Dalam Mereduksi Limbah Cair Industri Kelapa. Dalton : Jurnal Pendidikan Kimia Dan Ilmu Kimia, 2(2), 1-15.

Regaldo, L., Gervasio, S., Troiani, H., \& Gagneten, A. (2013). Bioaccumulation and Toxicity of Copper and Lead in Chlorella vulgaris. J. Algal Biomass Utln., 4(2), $59-66$. 
Dalton : Jurnal Pendidikan Kimia dan Ilmu Kimia, Volume 4 Nomor 1, Mei 2021

Sekabira, K., Origa, H. O., Basamba, T. A., Mutumba, G., \& Kakudidi, E. (2011). Application of algae in biomonitoring and phytoextraction of heavy metals contamination in urban stream water. International Journal of Environmental Science and Technology, 8(1), 115-128.

Shim, J. Y., Shin, H. S., Han, J. G., Park, H. S., Lim, B. L., Chung, K. W., \& Om, A. S. (2008). Protective effects of Chlorella vulgaris on liver toxicity in cadmiumadministered rats. Journal of Medicinal Food, 11(3), 479-485.

Singh, B. et. a. (2015). Algae and Environmental Sustainability. (F. Bux, Ed.), Developments in Applied Phycology 7 (Vol. 7). India.

Yonita Ike Putri Dyniari, Farikhah, \& Rahim, A. R. (2019). Dinamika Populasi Chlorela vulgaris Dalam Paparan Logam Berat Pb(II) dengan Konsentrasi Yang Berbeda Skala Laboratorium. Jurnal Perikanan Pantura (JPP), 2(1), 4-9.

Yun, H., Kim, I., Kwon, S.-H., Kang, J.-S., \& Om, A.-S. (2011). Protective Effect of Chlorella vulgaris against Lead-Induced Oxidative Stress in Rat Brains. Journal of Health Science, 57(3), 245-254.

Znad, H., Ketife, A. M. D. Al, Judd, S., Almomani, F., \& Vuthaluru, H. B. (2018). Bioremediation and nutrient removal from wastewater by Chlorella vulgaris. Ecological Engineering, 110(10), 1-7. 